\title{
Penerapan Model Exponential Smoothing berbasis Metode Evolutionary pada Kasus COVID-19 dan DBD di Bojonegoro
}

\author{
Denny Nurdiansyah ${ }^{1}$ dan Khoirul Wafa ${ }^{2}$
}

1Statistika, Universitas Nahdlatul Ulama Sunan Giri

2Pendidikan Bahasa Inggris, Universitas Nahdlatul Ulama Sunan Giri

denny.nur@unugiri.ac.id¹ dan khoirul.wafa@unugiri.ac.id²

Diajukan 18 Mei 2021 Diperbaiki 2 Agustus 2021 Diterima 10 Agustus 2021

\section{ABSTRAK}

Latar Belakang: COVID-19 menjadi perhatian utama di Bojonegoro karena kasus terinfeksi meningkat sampai akhir tahun 2020. Selain itu, wabah demam berdarah dengue (DBD) juga perlu diantisipasi di musim penghujan agar tidak meningkat bersamaan dengan wabah COVID-19.

Tujuan: Mengembangkan model exponential smoothing berbasis metode evolutionary untuk meramalkan banyaknya kasus terinfeksi COVID-19 dan DBD di Bojonegoro.

Metode: Penelitian diawali dengan pembuatan aplikasi peramalan model exponential smoothing dengan metode evolutionary dan pemrograman Visual Basic yang dikembangkan di Excel dan Solver. Koefisienkoefisien model dioptimasi secara iteratif dengan metode evolutionary dan metode generalized reduced gradient. Model tersebut dievaluasi kinerjanya dengan nilai mean absolute percentage error (MAPE), mean absolute deviation (MAD), dan mean squared error (MSE). Sumber data penelitian menggunakan data sekunder dari Dinas Kesehatan Bojonegoro yang berisi data harian kasus terinfeksi COVID-19 dan data bulanan kasus DBD.

Hasil: Model double exponential smoothing berbasis metode generalized reduced gradient menghasilkan kesalahan model peramalan yang lebih kecil untuk nilai MAPE, MAD, dan MSE. Hasil peramalan menunjukkan bahwa peningkatan terjadi pada periode ke depan untuk kasus terinfeksi COVID-19 yang lebih besar dibandingkan DBD.

Kesimpulan: Aplikasi peramalan model exponential smoothing dapat menjadi altenatif dalam meramalkan banyaknya kasus terinfeksi COVID-19 dan DBD di Bojonegoro.

Kata Kunci: exponential smoothing; evolutionary; generalized reduced gradient; COVID-19; DBD

\section{ABSTRACT}

Background: COVID-19 has become a main concern in Bojonegoro because the infected cases increaseduntil late years in 2020. Moreover, DBDepidemicshould be anticipated in rainy season so the infected case will notincrease to coincide with COVID-19epidemic.

Objective: To developand implementexponential smoothing model based on evolutionary method to forecast count of infected case on COVID-19 and DBD in Bojonegoro.

Method: This study was commenced by developingaforecasting applicationof exponential smoothingmodelwith evolutionary method and programming Visual Basic developed inExcel and Solver. The coefficients ofmodel were optimized iterative usingevolutionaryand generalized reduced gradient method. The model wasevaluated with mean absolute percentage error(MAPE), mean absolute deviation(MAD), dan mean squared error(MSE) value. Sourceofdata of research usedsecondary data from BojonegoroDistrict Health Officecontaining daily-monthlydata forCOVID-19 andDBD cases.

Results: Double exponential smoothingmodel based on generalized reduced gradient method. This method generatedfault of model smaller for MAPE, MAD, and MSE value. Result of forecasting showednext period improvement for COVID-19casesbiggerthan DBDcases.

Conclusion: Forecasting application of modelcan be alternative toforecast the infected casesofCOVID-19 and $D B D$ in Bojonegoro.

Keywords: exponential smoothing; evolutionary; generalized reduced gradient; COVID-19; DBD 
PENDAHULUAN

Coronavirus Disease 2019 (COVID-19) merupakan virus berbahaya yang menyebabkan masalah pernapasan dan radang paru-paru karena infeksi Severe Acute Respiratory Syndrome Coronavirus 2 (SARS-CoV-2) (Mus et al., 2021). Pada akhir tahun 2020 di laman resmi KPCPEN (2020) dilaporkan kasus bahwa kumulatif konfirmasi positif COVID-19 di Indonesia sudah mencapai 743.198 kasus, dengan rincian sembuh sebanyak 611.097 kasus dan meninggal sebanyak 22.138 kasus. Peningkatan ini terjadi terus menerus di berbagai daerah di Indonesia.

Wabah ini juga terjadi di Bojonegoro. Berdasarkan laporan akhir tahun 2020 dari laman resmi DIMKOMINFO Bojonegoro (2020), kumulatif konfirmasi positif COVID-19 di Bojonegoro mencapai 1287 orang dengan pasien yang dirawat 227 orang, sembuh 967 orang, dan meninggal 93 orang.

Adanya wabah COVID-19 ini menyebabkan kegiatan belajar mengajar menjadi kurang efektif. Hal ini disebabkan karena murid-murid masih butuh pendamping ketika melakukan pembelajaran berbasis online (Risalah et al., 2020).

Selain itu, Bojonegoro juga perlu mengantisipasi penyebaran wabah demam berdarah dengue (DBD) di musim penghujan. DBD dikenal sebagai penyakit yang disebabkan oleh virus dengue yang penularannya lewat gigitan nyamuk Aedesaegypti (Efendi et al., 2020).

Berdasarkan website resmi PEMKAB Bojonegoro (2019) pada tanggal 21 November 2019, sepanjang Oktober 2019 jumlah penderita DBD di Bojonegoro mencapai 404 orang dengan kematian 7 orang. Pada tahun 2018, terjadi jumlah kasus DBD sebanyak 589 orang dengan kematian 12 penderita.

Pada musim hujan, populasi nyamuk demam berdarah bakal meningkat, terlebih lagi saat memasuki perubahan musim dari kemarau ke penghujan atau musim pancaroba. Hal ini perlu diantisipasi agar banyaknya kasus terinfeksi DBD tidak meningkat bersamaan dengan wabah COVID-19.

Studi survei terkait sarana sanitasi pernah dilakukan di salah satu desa di Bojonegoro. Dari hasil penelitian diperoleh kesimpulan terkait perlunya ketersediaan jamban dan sarana pembuangan air limbah (SPAL) serta adanya sosialisasi pengelolaan sampah (Celesta dan Fitriyah, 2019).

Permasalahan biasanya muncul ketika pengambilan keputusan atau kebijakan kurang maksimal yang disebabkan oleh kurangnya pengetahuan data yang digali dari informasi data yang ada. Untuk menyelesaikan permasalahan ini diperlukan pengetahuan data berupa hasil peramalan yang membantu proses pengambilan keputusan yang berguna untuk memberikan masukan dalam kebijakan pemerintah dan stakeholders.

Berdasarkan hasil The M3-Competition dalam tulisan Wiyanti dan Pulungan (2012), model peramalan yang kompleks tidak menghasilkan peramalan yang lebih baik dari pada model yang lebih sederhana seperti model peramalan klasik. Dari semua model peramalan klasik, model yang baik untuk meramalkan deret waktu dengan pola tren adalah model exponential smoothing sebagaimana dijelaskan dalam Ostertagová dan Ostertag (2012).

Namun, model ini kurang baik ketika parameter model dihasilkan secara fixed value atau secara iteratif dengan konvergen lokal. Untuk mengantisipasi kekurangan ini, pada penelitian sebelumnya telah dilakukan penerapan model exponential smoothing berbasis metode generalized reduced gradient (GRG) oleh Ravinder (2016), tetapi terdapat kesulitan untuk mendapatkan nilai optimal yang konvergen dan berharap dilakukan percobaan dengan metode yang lain.

Metode yang sama digunakan oleh Karmaker (2017) pada kasus lain yang

https://jurnal.ugm.ac.id/jkesvo Published online August 31, 2021 
diperoleh hasil yang berbeda. Metode GRG ini dijelaskan secara terperinci dalam tulisan Nurdiansyah dan Kartini (2019).

Pada penelitian ini digunakan salah satu metode kecerdasan buatan, yaitu metode evolutionary. Yanch dan Wiechetek (2018) menjelaskan bahwa metode evolutionary digunakan pada software Solver yang merupakan suatu varietas dari genetic algorithm dan local search method yang diterapkan oleh individu di perusahaan Frontline Systems.

Genetic algorithm dibagi menjadi tiga tahapan yang dapat dipelajari dalam tulisan Kachitvichyanukul (2012). Sejauh ini penerapan kedua metode tersebut digunakan pada level lanjut bagi pengguna Microsoft Excel.

Pada penelitian ini diberikan suatu kebaruan dalam sistem operasi pengguna, yaitu otomatisasi. Sistem akan jalan dalam satu klik tombol running sehingga hal ini mempermudah pengguna dalam menerapkan sistem peramalan statistik yang memuat model exponential smoothing berbasis metode evolutionary.

Pengembangan model exponential smoothing berbasis metode evolutionary dilakukan dengan pembuatan sintaks program dalam panel pilihan toolbar developer dalam software Microsoft Excel dengan bahasa VBA Excel. VBA merupakan suatu macro dalam bentuk deretan perintah dan fungsi yang tersimpan di dalam modul Visual Basic Editor (VBE) (Hasana dan Alifiani, 2019).

Pengembangan model peramalan pada penelitian ini dilakukan dengan pembuatan sintaks program dengan bahasa VBA Excel dan bantuan Solver. Solver merupakan program add-in Microsoft Excel yang digunakan untuk what-if analysis (Yanch dan Wiechetek, 2018).

Pada penelitian ini, pengembangan model exponential smoothing berbasis metode evolutionary akan diberikan untuk meramalkan banyaknya kasus terinfeksi COVID-19 dan DBD di Bojonegoro. Diberikan pula metode generalized reduced gradient sebagai pembandingnya.

Masyarakat Bojonegoro diharapkan dapat menjaga kesehatan dan mematuhi protokol kesehatan, serta patuh terhadap anjuran pemerintah. Di samping itu, diperlukan masukan dalam kebijakan pemerintah untuk antisipasi saranaprasarana, obat-obatan dan tenaga medis di Bojonegoro. Dengan demikian, perlu dilakukan kajianpenulisan tentang penerapan model exponential smoothing berbasis metode evolutionary pada kasus COVID-19 dan DBD di Bojonegoro.

\section{METODE}

\section{A. Desain Penelitian}

Desain penelitian ini menerapkan pendekatan penelitian kuantitatif. Metode yang digunakan adalah membuat aplikasi peramalan model exponential smoothing dengan metode evolutionary dan pemrograman Visual Basic yang dikembangkan di Excel dan Solver. Sebagai pembanding, diberikan juga metode optimalisasi lain, yaitu metode generalized reduced gradient.

\section{B. Populasi dan Sampel}

Populasi penelitian adalah warga Bojonegoro yang terinfeksi COVID-19 atau DBD, sedangkan sampel yang digunakan adalah pasien yang terinfeksi COVID-19 atau DBD yang dirawat di RSUD Doktor R. Sosodoro Djatikoesoemo. Lokasi penelitian dilakukan di Dinas Kesehatan Kabupaten Bojonegoro selama tiga bulan yang dimulai pada tanggal 24 Februari 2021.

\section{Teknik Sampling}

Digunakan teknik sampling yaitu purposive sample yang mengambil data seadanya di lapangan sesuai tujuan penelitian. Sebagaimana penerapan studi kasusnya, sampel data historis dari kasus terinfeksi COVID-19 dan DBD masingmasing diambil seadanya di Dinas Kesehatan Kabupaten Bojonegoro. 


\section{Subjek Penelitian}

Sumber data penelitian adalah data sekunder dari Dinas Kesehatan Bojonegoro yang berisi data harian kasus terinfeksi COVID-19 pada tanggal $1 \mathrm{Mei}$ 2020 sampai 31 Desember 2020, serta data bulanan kasus DBD dicatat dari bulan Januari 2017 hingga Desember 2020. Variabel penelitian yang digunakan adalah kumulatif konfirmasi positif COVID-19 dan kumulatif pasien DBD yang berupa data diskrit dengan skala rasio.

\section{E. Teknik Analisis Data}

Pada teknik analisis data, pertama, proses akan menampilkan dan menganalisis data historis dengan ilustrasi grafik berupa time series plot. Kedua, dilakukan pengembangan model exponential smoothing berbasis metode evolutionary, lalu diberikan penerapan metode untuk meramalkan banyaknya kasus terinfeksi COVID-19 dan DBD di Bojonegoro. Sebagai pembanding, diberikan juga penerapan model exponential smoothing berbasis metode generalized reduced gradient.

Pada deret waktu yang memiliki pola tren, model exponential smoothing yang digunakan adalah model single exponential smoothing (SES) dan double exponential smoothing (DES). Berikut langkah-langkah pengembangan dan penerapan model exponential smoothing berbasis metode evolutionary dalam dua tahapan.

\section{Proses seleksi model}

1.1. Mengoptimalisasi parameter model SES dan DES masing-masing dengan metode evolutionary menggunakan Solver untuk meminimalkan nilai MSE.

1.2. Mengoptimalisasi parameter model SES dan DES masing-masing dengan metode generalized reduced gradient menggunakan Solver untuk meminimalkan nilai MSE. Mengevaluasi model dengan menghitung nilai kinerja model peramalan yang terbentuk, yaitu nilai MAPE, MAD, dan MSE.

Untuk mengukur kesalahan ramalan, digunakan residual model (et) dengan rumusan. Variabel $Y t$ mewakili nilai aktual sedangkan adalah nilai prediksi model. Kinerja model yang terbentuk dievaluasi dengan nilai mean absolute percentage error (MAPE), mean absolute deviation (MAD), dan mean squared error (MSE).

$$
\begin{gathered}
M A P E=\frac{100}{n} \sum_{t=1}^{n} \frac{\left|e_{t}\right|}{Y_{t}}, \\
M A D=\frac{1}{n} \sum_{t=1}^{n}\left|e_{t}\right|, \quad M S E=\frac{1}{n} \sum_{t=1}^{n}\left(e_{t}\right)^{2}
\end{gathered}
$$

\section{Proses peramalan model}

2.1. Menghitung nilai prediksi model dengan model SES, yaitu

$$
\hat{Y}_{t+1}=\alpha Y_{t}+(1-\alpha) \hat{Y}_{t}
$$

dan model DES berikut

$$
\begin{gathered}
L_{t}=\alpha Y_{t}+(1-\alpha)\left(L_{t-1}+T_{t-1}\right) \\
T_{t}=\beta\left(L_{t}-L_{t-1}\right)+(1-\beta) T_{t-1} \\
\hat{Y}_{t+1}=L_{t}+T_{t}
\end{gathered}
$$

2.2. Menghitung nilai residual model

$$
e_{t}=Y_{t}-\hat{Y}_{t}
$$

2.3. Menghitung nilai peramalan model untuk $\mathrm{p}$ periode ke depan bagi model SES yaitu

$\hat{Y}_{n+p}=\left\{\begin{array}{cc}\alpha Y_{n}+(1-\alpha) \hat{Y}_{n} & ; \text { untuk } p=1 \\ \hat{Y}_{n+p-1} & ; \text { untuk } p>1\end{array}\right.$

dan model DES diberikan

$$
\begin{aligned}
& \text { Untuk } \mathrm{p}=1, \text { maka } \\
& \begin{array}{c}
L_{n}=\alpha Y_{n}+(1-\alpha)\left(L_{n-1}+T_{n-1}\right) \\
T_{n}=\beta\left(L_{n}-L_{n-1}\right)+(1-\beta) T_{n-1} \\
\quad \hat{Y}_{n+p}=L_{n}+T_{n}
\end{array}
\end{aligned}
$$

Untuk $\mathrm{p}=2$, maka

$$
\begin{gathered}
L_{n+p-1}=\alpha \hat{Y}_{n+p-1}+(1-\alpha)\left(L_{n}+T_{n}\right) \\
T_{n+p-1}=\beta\left(L_{n+p-1}-L_{n}\right)+(1-\beta) T_{n} \\
\hat{Y}_{n+p}=L_{n+p-1}+T_{n+p-1}
\end{gathered}
$$

Untuk $\mathrm{p}>2$, maka

$$
\begin{aligned}
L_{n+p-1}= & \alpha \hat{Y}_{n+p-1}+(1-\alpha)\left(L_{n+p-2}+T_{n+p-2}\right) \\
T_{n+p-1}= & \beta\left(L_{n+p-1}-L_{n+p-2}\right)+(1-\beta) T_{n+p-2} \\
& \hat{Y}_{n+p}=L_{n+p-1}+T_{n+p-1}
\end{aligned}
$$


Penerapan Model Exponential Smoothing berbasis Metode...

2.4. Menghitung nilai interval peramalan model

$$
\begin{aligned}
& \text { Lower }_{n+p}=\hat{Y}_{n+p}-1.96 \operatorname{stdev}\left(e_{t}\right) \\
& \text { Upper }_{n+p}=\hat{Y}_{n+p}+1.96 \operatorname{stdev}\left(e_{t}\right)
\end{aligned}
$$

\section{HASIL DAN PEMBAHASAN}

Hasil

Pada kasus COVID-19, data pengamatan yang digunakan adalah data harian kumulatif konfirmasi positif COVID-19 pada tanggal 1 Mei 2020 sampai 31 Desember 2020, sedangkan pada kasus DBD digunakan data bulanan banyaknya pasien DBD pada bulan Januari 2017 sampai Desember 2020. Untuk mempermudah peramalan digunakan perhitungan kumulatif mulai bulan Januari 2017 sehingga pada kasus DBD digunakan data kumulatif pasien DBD. Berikut diberikan ilustrasi grafik berupa time series plot dari data harian kumulatif konfirmasi positif COVID-19 dan data bulanan kumulatif pasien DBD.

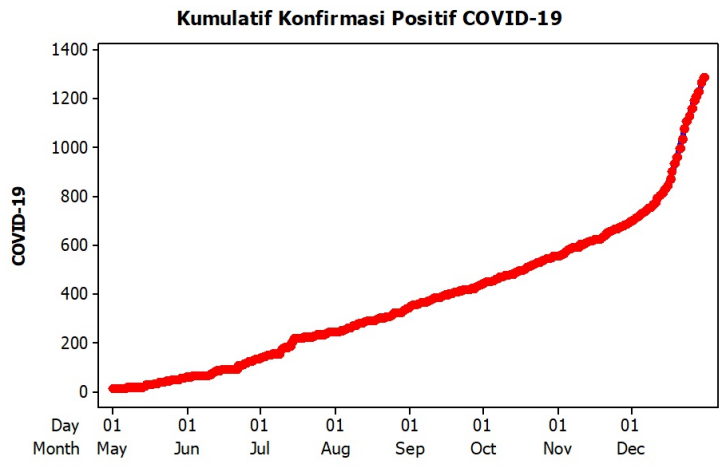

Gambar 1. Time series plot dari data harian kumulatif konfirmasi positif COVID-19.

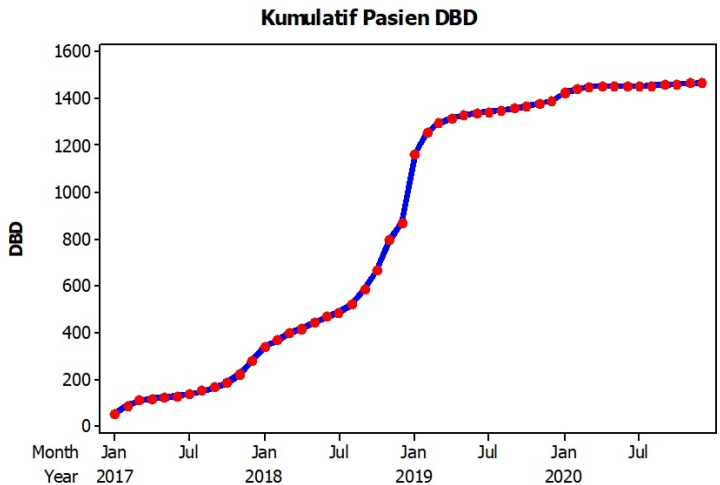

Gambar 2. Time series plot dari data bulanan kumulatif pasien DBD
Pada Gambar 1 ditampilkan pergerakan data deret waktu yang menunjukkan tren naik. Hal ini menunjukan bahwa pasien positif COVID19 terus meningkat. Bahkan, mendekati akhir tahun dan libur panjang diperoleh temuan kasus COVID-19 yang lebih tinggi, yaitu pada tanggal 23 Desember 2020 dengan konfirmasi positif COVID-19 sebanyak 1034 orang.

Di sisi lain pada output Gambar 2 untuk kasus DBD, pergerakan data historis juga diperoleh hasil tren naik meskipun ada perlambatan di akhir tahun. Hal ini menunjukan bahwa banyaknya pasien DBD terus meningkat pada Januari 2017 sampai Maret 2020. Kemudian, terjadi penurunan pada April 2020 dan seterusnya. Peningkatan pasien DBD tertinggi terjadi pada November 2018 dan Januari 2019, masing-masing sebanyak 131 dan 291 orang.

Hasil eksekusi untuk otomatisasi model exponential smoothing dengan metode evolutionary dan metode generalized reduced gradient diberikan pada Gambar 3. Dengan nilai awalan pada parameter model (Alpha dan Beta) sama dengan nol, nilai MSE secara otomatis akan mengikuti perhitungan sesuai persamaan (1). Dengan demikian, model yang terbentuk dari proses optimasi dapat terbentuk, kemudian semua hasil perhitungan kinerja model dengan nilai MAPE, MAD, dan MSE dengan

\begin{tabular}{|c|c|c|c|c|}
\hline SELECTION FOR MODELS & & & & \\
\hline Optimization Process & Method & MSE & Alpha & Beta \\
\hline Single Exponential Model & \multirow{2}{*}{ Evolutionary } & 80.09836066 & 1 & \\
\hline Double Exponential Model & & 14.6187408 & 0.84904884 & 0.531054475 \\
\hline Single Exponential Model & \multirow{2}{*}{ GRG } & 80.09836066 & \multirow{2}{*}{\begin{tabular}{|r|}
1 \\
0.908188618 \\
\end{tabular}} & \\
\hline Double Exponential Model & & 14.56338852 & & 0.44607135 \\
\hline Evaluation Process & Method & MAPE & MAD & MSE \\
\hline Single Exponential Model & \multirow{2}{*}{ Evolutionary } & 1.944011699 & 5.237704918 & 80.09836066 \\
\hline Double Exponential Model & & 1.78989785 & 2.541638866 & \begin{tabular}{|l|}
14.6187408 \\
\end{tabular} \\
\hline Single Exponential Model & \multirow{2}{*}{ GRG } & 1.944011699 & 5.237704918 & 80.09836066 \\
\hline Double Exponential Model & & 1.746081979 & 2.518946616 & 14.56338852 \\
\hline Run Optimization with Solver & \multicolumn{3}{|c|}{ Run Evaluation Model } & Reset \\
\hline
\end{tabular}
persamaan (1).

Gambar 3. Tampilan program pada proses seleksi model 
Setelah diperoleh parameter model terbaik, dihasilkan model peramalan seperti pada Gambar 4. Proses peramalan model dimulai dengan langkah pertama, yaitu memasukkan nilai parameter model terbaik (Alpha dan Beta) dan kedua, menekan tombol SES Model atau tombol DES Model masing-masing untuk menjalankan peramalan dengan model single exponential smoothing atau double exponential smoothing sesuai persamaan (2), persamaan (3), dan persamaan (4). Dengan demikian, akan diperoleh hasil peramalan model untuk beberapa periode ke depan berdasarkan persamaan (5), persamaan (6), dan persamaan (7). Pada penelitian ini, banyaknya periode peramalan ditentukan $10 \%$ dari banyaknya data pengamatan.

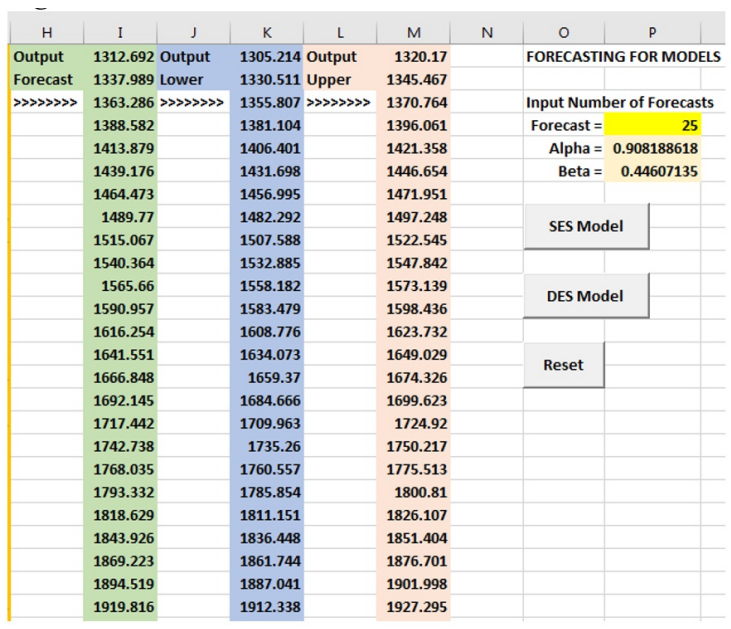

Gambar 4. Tampilan program pada proses peramalan model

Penerapan model peramalan diberikan untuk meramalkan banyaknya kasus terinfeksi COVID-19 dan DBD di Bojonegoro. Dari hasil penelitian ini, diperoleh secara ringkas tabel penilaian kinerja model pada proses seleksi model (Tabel 1 dan Tabel 2).

Tabel 1. Ringkasan hasil seleksi model untuk kasus COVID-19 (n1 = 245)

\begin{tabular}{clccccc}
\hline No. & \multicolumn{1}{c}{ Model } & Alpha & Beta & MAPE (\%) & MAD & MSE \\
\hline 1 & SES-Evolutionary & 1 & - & 1.9440 & 5.2377 & 80.0984 \\
2 & DES-Evolutionary & 0.8490 & 0.5311 & 1.7899 & 2.5416 & 14.6187 \\
3 & SES-GRG & 1 & - & 1.9440 & 5.2377 & 80.0984 \\
4 & DES-GRG & 0.9082 & 0.4461 & 1.7461 & 2.5189 & 14.5634 \\
\hline
\end{tabular}

Tabel 2. Ringkasan hasil seleksi model untuk kasus DBD (n2 = 48)

\begin{tabular}{ccccccc}
\hline No. & \multicolumn{1}{c}{ Model } & Alpha & Beta & MAPE (\%) & MAD & MSE \\
\hline 1 & SES-Evolutionary & 1 & - & 6.3961 & 30.0425 & 3123.6596 \\
2 & DES-Evolutionary & 0.9550 & 0.4415 & 4.2338 & 22.6909 & 1791.3713 \\
3 & SES-GRG & 1 & - & 6.3961 & 30.0426 & 3123.6596 \\
4 & DES-GRG & 0.9540 & 0.5940 & 4.0601 & 21.6132 & 1751.6181 \\
\hline
\end{tabular}

Hasil model terbaik ditunjukan oleh model double exponential smoothing (DES) dengan nilai MAPE dibawah 5\%. Untuk kasus COVID-19, kinerja model peramalan hampir sama meskipun metode GRG sedikit lebih unggul dari metode Evolutionary. Di sisi lain pada kasus DBD, terlihat jelas metode GRG lebih baik dari pada metode Evolutionary dalam model peramalan.

Pada penelitianini, peramalan model diberikan dengan periode sebanyak $10 \%$ dari banyaknya data pengamatan. Dengan demikian, banyaknya periode peramalan pada kasus COVID-19 dan DBD masingmasing sebanyak 25 periode (1 Januari
2021-25 Januari 2021) dan 5 periode (Januari-Mei 2021). Hasil peramalan dari model terbaik, yaitu model double exponential smoothing berbasis metode generalized reduced gradient (Tabel 3).

Tabel 3. Ringkasan hasil peramalan model untuk kasus COVID-19 dan DBD

\begin{tabular}{cccc}
\hline No & Kasus & Periode & Peramalan \\
\hline 1 & Covid-19 & 1 & $1312(1305-1320)$ \\
& $\left(p_{1}=25\right)$ & 2 & $1337(1330-1345)$ \\
& & 3 & $1363(1355-1370)$ \\
& & 4 & $1388(1381-1396)$ \\
& & 6 & $1413(1406-1421)$ \\
& & 7 & $1439(1431-1446)$ \\
& & 9 & $1464(1456-1471)$ \\
& & 10 & $1515(1507-1497)$ \\
& & &
\end{tabular}


Penerapan Model Exponential Smoothing berbasis Metode...

Tabel 3. Ringkasan hasil peramalan model untuk kasus COVID-19 dan DBD (lanjutan..)

\begin{tabular}{cccc}
\hline No & Kasus & Periode & Peramalan \\
\hline & & 11 & $1565(1558-1573)$ \\
& & 12 & $1590(1583-1598)$ \\
& & 13 & $1616(1608-1623)$ \\
& & 14 & $1818(1811-1826)$ \\
& & 16 & $1843(1836-1851)$ \\
& 17 & $1869(1861-1876)$ \\
& 18 & $1994(1887-1902)$ \\
& 19 & $1641(1912-1927)$ \\
& 20 & $1666(1659-1649)$ \\
& 21 & $1692(1684-1699)$ \\
& 22 & $1717(1709-1724)$ \\
& & 23 & $1742(1735-1750)$ \\
& & 24 & $1768(1760-1775)$ \\
2 & DBD & 1 & $1493(1785-1800)$ \\
& $($ p2 = 5) & 2 & $1470(1385-1551)$ \\
& & 3 & $1473(1398-1553)$ \\
& & 4 & $1475(1393-1556)$ \\
& & 5 & $1478(1395-1561)$ \\
\hline
\end{tabular}

\section{Pembahasan}

Tren naik pada data kumulatif dijelaskan sebagai suatu peningkatan, sedangkan penurunan diilustrasikan dengan adanya perlambatan atau garis mendatar di periode-periode berikutnya. Hasil yang diberikan pada kasus COVID19 menunjukkan peningkatan drastis yang muncul ketika menjelang akhir tahun yang bertepatan dengan libur panjang. Namun, hasil berlawanan dengan kasus DBD yang menurun sehingga memunculkan tanda tanya dan perlu adanya penyelidikan tentang kejadian ini mengingat di periode-periode sebelumnya banyak yang terinfeksi.

Pada penelitian ini, metode GRG secara iteratif menghasilkan parameter model yang optimal, sedangkan metode evolutionary kurang optimal dalam optimalisasi parameter model karena prosesnya cenderung lebih lama yang akhirnya terhenti dan memberikan alasan kalau solusi sudah tidak dapat ditingkatkan lagi. Hal ini disebabkan proses optimalisasi secara iteratif telah mencapai batas maksimal iterasi sehingga hasil yang diperoleh adalah hasil terakhir iterasi dan kurang optimal.

Data pengamatan pada kasus COVID-
19 mewakili sampel besar, sedangkan pada kasus DBD menggambarkan sampel kecil. Pada sampel besar model exponential smoothing memiliki kinerja yang baik, tetapi kinerjanya masih kurang baik untuk sampel kecil. Hal ini dikarenakan sampel besar memiliki varian yang lebih kecil daripada sampel kecil.

Hasil peramalan yang dihasilkan pada penelitian ini merupakan bagian awal dari proses pengambilan keputusan dan berguna untuk masukan dalam kebijakan pemerintah untuk antisipasi sarana-prasarana, obat-obatan dan tenaga medis di Bojonegoro. Dengan demikian, hasil peramalan ini berguna untuk input pengambilan keputusan dalam mengatisipasi peningkatan kasus terinfeksi COVID-19 dan DBD.

\section{PENUTUP}

\section{Kesimpulan}

Pergerakan tren pada data kumulatif COVID-19 menunjukkan peningkatan sedang dengan tren naik tinggi, sedangkan pada data kumulatif DBD menunjukkan peningkatan dan perlambatan. Kinerja model terbaik diberikan oleh model double exponential smoothing berbasis metode generalized reduced gradient. Ukuran sampel yang besar akan mempengaruhi kinerja model peramalan.

Model yang dikembangkan memiliki kelebihan dalam hal otomisasi hasil peramalan. Model yang terbentuk berbasis metode generalized reduced gradient memiliki kecepatan iterasi yang lebih baik daripada metode evoluationary. Penggunaan peramalan berguna untuk input pengambilan keputusan dalam mengantisipasi peningkatan kasus terinfeksi COVID-19 dan DBD.

\section{Saran}

Penurunan kasus DBD di Bojonegoro perlu diselidiki terkait faktor-faktor yang mempengaruhinya. Kinerja model terkendala pada sampel kecil yang 
memiliki sifat/regime lebih dari satu yang mana bisa dicobakan pada metode peramalan pada tingkat lebih lanjut. Pengembangan model pada penelitian ini bisa menjadi masukan untuk modelmodel peramalan lain yang terkendala proses optimalisasi parameter model.

\section{DAFTAR PUSTAKA}

Celesta, A. G. and Fitriyah, N. (2019) 'Overview Basic Sanitation In Payaman Village, Bojonegoro District 2016', Jurnal Kesehatan Lingkungan, 11(2), pp. 83-90. doi: 10.20473/ jkl.v11i2.2019.83-90.

DIMKOMINFO Bojonegoro (2020) Update data COVID-19 Bojonegoro. Available at: lawancorona.bojonegorokab.go.id (Accessed: 31 December 2020).

Efendi, Y., Khayudin, B. and Julianto, E. (2020) 'SAMA RASA DEBAR (Sehat Bersama Masyarakat Sadar Demam Berdarah)', Jurnal HUMANIS, 5(1), pp. 37-41.

Hasana, S. N. and Alifiani (2019) 'Multimedia Development Using Visual Basic for Application (VBA) to Improve Students' Learning Motivation in Studying Mathematics of Economics', Indonesian Journal of Mathematics Education, 1(1), pp. 34-42. doi: 10.31002/ijome.v2i1.1230.

Kachitvichyanukul, V. (2012) 'Comparison of Three Evolutionary Algorithms: GA, PSO, and DE', Industrial Engineering and Management Systems, 11(3), pp. 215-223. doi: 10.7232/ iems.2012.11.3.215.

Karmaker, C. L. (2017) 'Determination of Optimum Smoothing Constant of Single Exponential Smoothing Model: A Case Study', International Journal of Research in Industrial Engineering, 6(3), pp. 184-192. doi: 10.22105/ riej.2017.49603.

KPCPEN (2020) Update data COVID-19 Indonesia. Available at: covid19.go.id (Accessed: 31 December 2021).
Tinjauan Pemeriksaan Laboratorium pada Pasien COVID-19', Jurnal Kesehatan Vokasional, 5(4), pp. 242-252. doi: $10.22146 /$ jkesvo.58741.

Nurdiansyah, D. and Kartini, A. Y. (2019) 'Algoritma Generalized Reduced Gradient Berbasis Markov-Switching Model Untuk Optimisasi Portofolio Saham Perbankan Di Indonesia', Media Bina Ilmiah, 13(10), pp. 20952108. doi: 10.33758/mbi.v14i2.369.

Ostertagová, E. and Ostertag, O. (2012) 'Forecasting using simple exponential smoothing method', Acta Electrotechnica et Informatica, 12(3), pp. 62-66. doi: 10.2478/v10198-012-0034-2.

PEMKAB Bojonegoro (2019) Dinkes Himbau Masyarakat Waspada DBD Di Musim Pancaroba. Available at: bojonegorokab.go.id (Accessed: 21 October 2019).

Ravinder, H. V. (2016) 'Determining The Optimal Values Of Exponential Smoothing Constants - Does Solver Really Work?', American Journal of Business Education (AJBE), 9(1), pp. 114. doi: 10.19030/ajbe.v9i1.9574.

Risalah, A. et al. (2020) 'Dampak Pandemi Covid-19 Terhadap Kegiatan Belajar Mengajar Di MI/SD (Studi KBM Berbasis Daring Bagi Guru dan Siswa)', Journal of Islamic Education at Elementary School, 1(1), pp. 10-16. doi: 10.47400/jiees.v1i1.5.

Wiyanti, D. T. and Pulungan, R. (2012) 'Peramalan Deret Waktu Menggunakan Model Fungsi Basis Radial (RBF) Dan Auto Regressive Integrated Moving Average (ARIMA)', Indonesian Journal of Mathematics and Natural Sciences, 35(2), pp. 175-182.

Yanch, U. and Wiechetek, Ł. (2018) 'Task Assignment Optimization with the Use of PESBAT Linear Programming Tool', Annales Universitatis Mariae Curie-Skłodowska, sectio H, Oeconomia, 52(2), pp. 185-198. doi: 10.17951/ h.2018.52.2.185-198.

Mus, R. et al. (2021) 'Studi Literatur: 